\title{
DESIGNING THE READING MODULE IN AN ESP COURSE FOR THE STUDENTS MAJORING IN RADIO ENGINEERING, TELECOMMUNICATIONS AND ECONOMIC STUDIES
}

\author{
NATALIIA ZHUKOVA \\ National University 'Zaporizhzhia Polytechnic', Ukraine
}

\section{IRYNA DIDENKO}

Taras Shevchenko National University of Kyiv, Ukraine

\begin{abstract}
An English for Specific Purposes (ESP) course aims to enable students to function effectively in their ever-changing, all the more global professional environment. For such a course to be efficient, an ESP syllabus is to be constantly updated. This study focused on the design of the Reading module in an ESP course taught to the $1^{\text {st }}$-year students of Radio Engineering and Telecommunications Faculty at Zaporizhzhia National Technical University and students of the Faculty of Economics at Taras Shevchenko National University of Kyiv. Students' learning experience was outlined by them with the help of the questionnaires concerning before-, while- and post-reading strategies. Reading subskills to be improved were identified taking into account the results of the comparative analysis of the reading subskills that are assessed in international examinations for academic and occupational purposes (BULATS, GMAT, OET, TOEFL ITP, etc.). The material for developing the reading subskills was decided upon regarding a set of text selection criteria. Then authentic and learning tasks were set. Finally, some practical recommendations for designing the Reading module in the ESP syllabus were given.
\end{abstract}

Key words: authentic text, English for Specific Purposes course, reading skill, reading strategy, reading subskill

\section{INTRODUCTION}

Reading is considered to be one of the most important skills for educational and professional success, as it reinforces the learner's other skills (Alemi and Ebadi, 2010: 269-270). It both provides access to the pool of data gathered by 
the experts in the field of professional interest and comes into the foreground in the international examinations that are required for the academic mobility programmes and when applying for a job.

An English for Specific Purposes (ESP) course is basically about helping students to build up their expertise while studying their specialism and doing their jobs using English. Thus, the need of the learners to be good at reading via extracting, analyzing and summarizing information is to be met.

The goal of this study is to work out the guidelines for designing the Reading module as a component of the ESP syllabus. To reach the goal, the most efficient reading strategies and the activities for developing reading skills are to be identified here. To make the learning process relevant to the students' professional needs, the texts are to be selected regarding a set of criteria.

\section{LITERATURE REVIEW}

Teaching reading in the ESP courses has been the subject of scientific interest from different perspectives: the methodology for an ESP reading skills course designed for undergraduate medical students (Çelika and Topkayab, 2016), the role of translation in developing the reading comprehension skills of ESP learners (Rushwan, 2017), the effects of pre-reading activities on reading comprehension of L2 learners of science and technology majors (Alemi and Ebadi, 2010).

For our study, it is important to note that teaching reading strategies is more efficient than traditional reading instruction (Reza, 2013: 19). Thus, the cognitive reading strategies most commonly used by EFL students have been identified (Ozek and Civelek, 2006; Ratna, 2014). In the scientific papers on this approach to teaching reading in ESP, the reading strategies commonly used by ESP students of medical sciences have been examined (Omar, 2014), the effect of strategies-based ESP instruction on developing male and female management students' reading comprehension has been researched (Kashef, 2012).

However, teaching reading strategies to the students of Radio Engineering, Telecommunications and Economic Studies in ESP courses requires particular attention with the increased popularity of international examinations in Ukraine. In our study, self-report questionnaires were applied as listed in Bezci (1998: 5051). It should be noted that these questionnaires were used along with the ThinkAloud Protocols in the investigation by Ratna (2014), following Ozek and Civelek (2006). Four strategies used at high frequency were identified then, without giving any specific recommendations for their development. There were three texts adopted from Longman Preparation Course for TOEFL test (Ratna, 2014: 6), but no other international examinations were in the focus of the researchers' attention as far as teaching reading strategies is concerned. 


\section{METHODS}

Following Afflerbach, Pearson and Paris (2008: 368), we regard reading strategies as 'deliberate, goal-directed attempts to control and modify the reader's efforts to decode text, understand words, and construct meanings of text', while reading skills are considered to be 'automatic actions that result in decoding and comprehension with speed, efficiency, and fluency and usually occur without awareness of the components or control involved'.

When designing an ESP course in Ukraine, several documents are to be regarded: English for Specific Purposes (ESP). National Curriculum for Universities (Bakaieva, et al. 2005) and the requirements of the international examinations. The examinations considered in the paper are required abroad for entering a university (e.g. for Master's degree programmes) or applying for a grant or a job. In order to select or design relevant materials for teaching reading in an ESP course, we took into account the reading subskills tested in 11 international examinations in the field of ESP, English for Academic Purposes (EAP) and Business English, and the types of tasks set to assess the reading skills.

The study focused on designing the Reading module in an ESP course taught to the first-year students of Radio Engineering and Telecommunications Faculty at Zaporizhzhia National Technical University (ZNTU, now - National University 'Zaporizhzhia Polytechnic') and the fist-year students of the Faculty of Economics at Taras Shevchenko National University of Kyiv. There were 9 and 11 people involved respectively. The study took place within one semester in the academic year of 2018-2019.

The reading comprehension subskills and types of tasks used in the following international Business English examinations were in the centre of our attention (see Appendix 1, Table 1):

- B1 Business Preliminary;

- B2 Business Vantage;

- C1 Business Higher;

- BULATS (Business Language Testing Service);

- GMAT (Graduate Management Admission Test).

As it can be seen from Table 1 (Appendix 1), in all Business English examinations, but GMAT, such reading subskills as skimming and scanning are tested besides others.

Other international ESP and EAP examinations that we analyzed were as follows:

- TOEFL ITP (Test of English as a Foreign Language: Institutional Testing Program);

- OET (Occupational English Test);

- TOEIC (Test of English for International Communication); 
- IELTS Academic (International English Language Testing System: Academic);

- TOLES (Test of Legal English Skills): Foundation Exam, Higher Exam, Advanced Exam;

- PTE Academic (Pearson Test of English: Academic).

All of the ESP and EAP examinations listed in this paper (see Appendix 1, Table 2) are similar in their testing such reading subskills as scanning and skimming. The prevalent majority of the examinations are also about being able to infer and deduce meaning from context; only PTE Academic differs by testing understanding the structure of the text in addition to scanning and skimming.

Taking into account the reading objectives for B2 Level (Bachelor's Language Proficiency) stated in the English for Specific Purposes (ESP). National Curriculum for Universities (Bakaieva et al., 2005: 37), and the subskills tested in the international examinations listed above, the learning outcomes for the Reading module were as follows.

By the end of the Reading module students will be able to

- understand authentic texts related to the study or specialism areas (Radio Engineering and Telecommunications, Economic Studies respectively);

- identify writer's attitudes and viewpoints in authentic texts related to academic or professional area;

- understand details in fairly complex instructions, specifications, advertising materials, articles;

- understand authentic academic and professional correspondence;

- comprehend different registers.

In order to reach the stated outcomes, authentic texts regarding a set of text selection criteria (e.g. authenticity, suitability of content, variety) were used (see Dudley and St. John, 2012: 96-99) and the following types of activities were used in the study:

- Predicting what the text is about based on the title / first line of each paragraph

- Formulating the main idea(s) of the text

- Matching paragraphs with the headlines

- Rearranging the sentences / paragraphs

- Making a plan

- Filling in the gapped texts

- Doing a multiple-choice quiz

- Reading for specific information

- Identifying 'True / False / Not Given’ statements

- Presenting the content in a mindmap

- Jigsaw reading

- Deciding which text the information comes from 
- Explaining unfamiliar words based on the context

- Classifying the words according to their meaning

- Classifying the words according to their grammatical category

- Inferring writer's view.

One or two activities out of the list were designed for a particular text related to the students' specialism.

Students' learning experience was outlined with the help of the questionnaires (listed in Bezci, 1998: 50-51) that concern the exploitation of pre-, while-, and post-reading strategies. At the beginning and the end of the term, the students were asked to identify the frequency with which they use a particular reading strategy (Appendix 2). The students had to tick the box which is true of them opposite to each reading strategy: 'Always true of me', 'Usually true of me', 'Sometimes true of me', 'Rarely true of me', 'Never true of me'.

The results of the survey are presented in Tables 1 and 2 below. Top five strategies in each category (pre-, while- and post-reading strategies) were selected.

\section{RESULTS AND DISCUSSION}

Our study has proved the efficiency of focusing on reading strategies and using the kinds of activities typical of the international examinations in the ESP courses for the first-year students of Radio Engineering, Telecommunications and Economic Studies. This claim can be supported by the fact that the students' preferences for the reading strategies changed after we made emphasis on the activities used in the international examinations while designing the Reading module for our ESP courses.

The analysis of the Rating of the reading strategies used by the students of Radio Engineering and Telecommunications Faculty at ZNTU before and after the experimental study (Table 1) has revealed the following findings.

As far as the pre-reading strategies are concerned, before the approach to teaching reading was changed with the focus on reading strategies, the students of ZNTU relied mostly on the gist reading to get the main idea. Their next priorities were resorting to the visuals to get a better understanding of the text and predicting the content based on the title. Less popular was relating the topic of the text to their background knowledge and reading the first line of every paragraph to understand what the text was about.

When considering while-reading strategies, the students admitted looking up some important words in the dictionary quite often. In order to understand the meaning of a particular sentence, they frequently considered the other sentences in the paragraph. Rereading a sentence was the third strategy in the ranking. Less frequently, the students made guesses about what would come next based on the information already given in the text. A few students relied on having the picture of the events in the text in mind. 
Table 1 Rating of the reading strategies used by the students of Radio Engineering and Telecommunications Faculty at ZNTU before and after the experimental study

\begin{tabular}{|l|}
\hline $\begin{array}{l}\text { Pre-reading strategies } \\
\text { (before the experimental study) }\end{array}$ \\
\hline $\begin{array}{l}\text { 1. Reading over the text quickly to get } \\
\text { the main idea (44\% 'Always true of me', } \\
\text { 33\% 'Usually true of me') }\end{array}$ \\
2. Looking at illustrations/pictures and \\
guessing how they relate to the text \\
(22\% 'Always true of me', $44 \%$ 'Usually \\
true of me') \\
3. Reading the title and imagining what \\
the text might be about (11\% 'Always \\
true of me', $44 \%$ 'Usually true of me') \\
4. Thinking about previous knowledge \\
about the topic of the text (11\% 'Always \\
true of me', 22\% 'Usually true of me, \\
56\% 'Sometimes true of me') \\
5. Reading the first line of every paragraph \\
to understand what the text is about \\
(11\% 'Usually true of me', 56\% \\
'Sometimes true of me')
\end{tabular}

While-reading strategies (before the experimental study)

1. Using the dictionary for the important words ( $56 \%$ 'Always true of me', $22 \%$ 'Usually true of me')

2. Considering the other sentences in the paragraph to figure out the meaning of the sentence ( $56 \%$ 'Usually true of me', $22 \%$ 'Always true of me')

3. Rereading a sentence ( $33 \%$ 'Always true of me', 33\% chose 'Usually true of me')

4. Making guesses about what will come next based on the information already given in the text (22\% 'Always true of me', 33\% 'Usually true of me', $45 \%$ "Sometimes true of me')

5. Having the picture of the events in the text in mind (22\% 'Sometimes true of me', $22 \%$ 'Always true of me', 33\% 'Usually true of me').
Pre-reading strategies

(after the experimental study)

1. Looking at illustrations/pictures and guessing how they relate to the text (57\% 'Always true of me', 29\% 'Usually true of me')

2. Reading the title and imagining what the text might be about (43\% 'Always true of me', $43 \%$ 'Usually true of me')

3. Reading over the text quickly to get the main idea (gist) (14\% 'Always true of me, $57 \%$ 'Usually true of me')

4. Thinking about previous knowledge on the topic of the text (14\% 'Always true of me', $29 \%$ 'Usually true of me')

5. Reading the first line of every paragraph to understand what the text is about (14\% 'Always true of me', 14\% 'Usually true of me', $43 \%$ 'Sometimes true of me')

\section{While-reading strategies}

(after the experimental study)

1. Relating the text to background knowledge about the topic to remember important information (33\% 'Always true of me', 29\% 'Usually true of me', 29\% 'Sometimes true of me')

2. Using the dictionary for important words (33\% 'Always true of me', 29\% 'Usually true of me', 14\% 'Sometimes true of me')

3. Having the picture of the events in the text in mind (29\% 'Always true of me, $71 \%$ 'Usually true of me')

4. Reading without translating word-forword (29\% 'Always true of me', 29\% 'Usually true of me', 33\% 'Sometimes true of me')

5. Skipping words (29\% 'Always true of me', $29 \%$ 'Usually true of me', $14 \%$ 'Sometimes true of me')

\section{Post-reading strategies (before the experimental study)}

1. Rereading the text to remember important points (45\% 'Always true of me', $45 \%$ 'Usually true of me')
Post-reading strategies

(after the experimental study)

1. Summarizing the main ideas (71\% 'Always true of me', 14\% 'Usually true of me') 
2. Rereading the text to remedy the comprehension failures $(22 \%$ 'Always true of me', 67\% 'Sometimes true of me')

3. Summarizing the main ideas $(33 \%$ 'Always true of me', 22\% 'Sometimes true of me')

4. Classifying the words according to their meaning (22\% 'Always true of me', $11 \%$ 'Usually true of me', 56\% 'Sometimes true of me')

5. Classifying the words according to their grammatical category ( $11 \%$ 'Always true of me', $11 \%$ 'Usually true of me', $44 \%$ 'Sometimes true of me')
2. Rereading the text to remember important points (33\% 'Always true of me', 29\% 'Usually true of me')

3. Classifying the words according to their meaning (29\% 'Always true of me', 33\% 'Usually true of me')

4. Rereading the text to remedy the comprehension failures (14\% 'Always true of me', 57\% 'Usually true of me')

5. Classifying the words according to their grammatical category (33\% 'Usually true of me', 29\% 'Sometimes true of me')

As for the post-reading strategies, rereading the text to remember important points headed the ranking. Rereading the text to remedy the comprehension failures was practiced more often than summarizing the main ideas. Classifying the words according to their meaning or their grammatical category was less popular among the respondents.

After the introduction of the activities that were aimed at developing more efficient reading strategies, the survey showed that there was a shift in the approach that the students used to deal with the texts.

The priority given to taking into account the visuals and predicting the content based on the title before reading for the gist seems to be a positive change. These top strategies help to quickly get ready for perceiving the info, they scaffold understanding it. However, more work needs to be done to demonstrate to the students the importance of relating the topic to their background knowledge even at the pre-reading stage. This might be beneficial for the readers making them more confident and providing the context for acquiring some new data.

The comparison of the most popular while-reading strategies before and after the study led us to the conclusion that students started to give preference to relating the text to their background knowledge when reading the text to remember some significant information. They still relied on the dictionary for important words. Having the picture of the events in mind moved higher in the ranking, coming before reading without translating word-for-word and skipping words. This way, students acquired some useful techniques for their professional life when large amounts of information need to be dealt with.

The fact that summarizing the main ideas came to the top of the rating with a big margin is a positive achievement. Giving preference to rereading the text to remember some data before classifying the words either according to the meaning or grammatical category is also helpful for enhancing reading skills. Still, rereading the text to remedy the comprehension failures seems to be worth 
further working on as it is essential for avoiding the mistakes that might influence the performance of a job-related task.

After the Rating of the reading strategies used by the students of the Faculty of Economics at Taras Shevchenko National University of Kyiv before and after the experimental study (Table 2) was analyzed, the results were as follows.

\section{Table 2 Rating of the reading strategies used by the students of the Faculty of Economics at Taras Shevchenko National University of Kyiv before and after the experimental study}

\section{Pre-reading strategies (before the experimental study) \\ 1. Reading the title and imagining what the text might be about (36\% 'Always true of me', $36 \%$ 'Usually true of me') \\ 2. Looking at illustrations/pictures and guessing how they relate to the text (27\% 'Always true of me', 36\% 'Usually true of $m e$ ')}

3. Reading over the text quickly to get the main idea (gist) (9\% 'Always true of me', 36\% 'Usually true of me')

4. Thinking about previous knowledge on the topic of the text (9\% 'Always true of me', $18 \%$ 'Usually true of me', $55 \%$ 'Sometimes true of me')

5. Reading the first line of every paragraph to understand what the text is about (9\% 'Always true of me', 18\% 'Usually true of me', 27\% 'Sometimes true of me')

\section{While-reading strategies} (before the experimental study)

1. Using the dictionary for the important words (55\% 'Always true of me', 36\% 'Usually true of me')

2. Considering the other sentences in the paragraph to figure out the meaning of the sentence (36\% 'Always true of me', $27 \%$ 'Usually true of me', 36\% 'Sometimes true of me')

3. Guessing the meaning of a word from the context (27\% 'Always true of me', 36\% 'Usually true of me', $27 \%$ 'Sometimes true of me')

4. Having the picture of the events in the text in mind (27\% 'Always true of me', $27 \%$ 'Usually true of me', $27 \%$ 'Sometimes true of me')
Pre-reading strategies (after the experimental study)

1. Reading the title and imagining what the text might be about (50\% 'Always true of me', $32 \%$ 'Usually true of me')

2. Thinking about previous knowledge on the topic of the text (38\% 'Always true of me', $32 \%$ 'Usually true of me')

3. Reading the first line of every paragraph to understand what the text is about (24\% 'Always true of me', 43\% 'Usually true of me')

4. Looking at illustrations/pictures and guessing how they relate to the text (20\% 'Always true of me', 39\% 'Usually true of me')

5. Reading over the text quickly to get the main idea (gist) (16\% 'Always true of me', $14 \%$ 'Usually true of me', $28 \%$ 'Sometimes true of me')

\section{While-reading strategies} (after the experimental study)

1. Relating the text to background knowledge about the topic to remember important information (38\% 'Always true of me', 24\% 'Usually true of me')

2. Guessing the meaning of a word from the context (38\% 'Always true of me', $30 \%$ 'Usually true of me')

3. Considering the other sentences in the paragraph to figure out the meaning of the sentence (25\% 'Always true of me, 25\% 'Usually true of me')

4. Paying attention to words or phrases that show how the text is organized (25\% 'Always true of me', 20\% 'Usually true of me', $15 \%$ 'Sometimes true of me') 
5. Reading without translating word-forword (18\% 'Always true of me', $64 \%$ 'Usually true of me')

\section{Post-reading strategies}

(before the experimental study)

1. Classifying the words according to their meaning (46\% 'Always true of me', 9\% 'Usually true of me', 27\% 'Sometimes true of me')

2. Summarizing the main ideas $(36 \%$ 'Always true of me', 46\% 'Usually true of me', $18 \%$ 'Sometimes true of me')

3. Rereading the text to remember important points (9\% 'Always true of me', $46 \%$ 'Usually true of me', $36 \%$ 'Sometimes true of me')

4. Rereading the text to remedy the comprehension failures (9\% 'Always true of me', 9\% 'Usually true of me', $82 \%$ 'Sometimes true of me')

5. Classifying the words according to their grammatical category ( $9 \%$ 'Usually true of me', $73 \%$ 'Sometimes true of me')
5. Guessing the meaning of the word from the grammatical category (25\% 'Always true of me', $12 \%$ 'Usually true of me', $10 \%$ 'Sometimes true of me')

\section{Post-reading strategies}

(after the experimental study)

1. Rereading the text to remedy the comprehension failures (78\% 'Always true of me', 36\% 'Usually true of me')

2. Summarizing the main ideas ( $54 \%$ 'Always true of me', 30\% 'Usually true of me')

3. Rereading the text to remember important points (46\% 'Always true of me', $25 \%$ 'Usually true of me')

4. Classifying the words according to their meaning (22\% 'Always true of me', 20\% 'Usually true of me', 30\% 'Sometimes true of me')

5. Classifying the words according to their grammatical category (15\% 'Always true of me', $15 \%$ 'Usually true of me', $25 \%$ 'Sometimes true of me')

Before the experimental study, the first-year students resorted mainly to reading the title and predicting the content of the text. They also relied on illustrations/pictures to correlate them with the text. Some of the students read for the gist and fewer people thought about their previous knowledge on the topic of the text. Reading the first line of every paragraph was the least popular strategy.

Among the while-reading strategies, using the dictionary ranked the highest. Students considered the other sentences in the paragraph to figure out the meaning of the sentence less frequently. They guessed the meaning of the word from the context seldom. However, it happened more often than the picture of the events was formed and students read without translating wordfor-word.

As for the post-reading strategies, respondents classified the words according to their meaning frequently. Summarizing the main ideas was practiced less often, but it prevailed over rereading the text to remember some important points. Rereading to remedy the comprehension failures turned out to be unpopular. Still fewer people classified the words according to their grammatical category.

After the study, reading the title remained the top priority for the students among the pre-reading strategies. Thinking about their previous knowledge on the topic was acknowledged to become more helpful than before. Reading the first line of the paragraph was found more useful, while illustrations were 
resorted to after that. Finally, reading for the gist was practiced more often, which had not been among the top strategies before. By applying the abovementioned reading strategies, the students could get a lot of information about the text before actually reading it.

The ranking of the while-reading strategies shows that students started to rely more on their background knowledge, exercise their ability to guess, consider the linkers that signpost the structural elements of the text. The respondents also became more used to guessing the meaning based on the grammatical category. These transformations in the preferences made students less dependent on the word-for-word translation and dictionaries.

The choice of the most helpful post-reading strategies did not change much. Summarizing the main ideas, rereading the text to remember important points and classifying the words according to their grammatical category retained their position among the frequently used strategies. However, rereading the text to remedy the comprehension failures started to be regarded as the most beneficial of all.

When regarding the changes that were revealed in the choice of reading strategies used by the ESP learners at the universities participating in the experimental study, the following findings were revealed.

The students became more autonomous readers, they started to resort more to predicting what the text is about based on their background knowledge and using visuals for that purpose. These are positive trends from the perspective of preparing students to operate in real-life situations when a lot of information has to be processed quickly and efficiently.

In order to improve the reading skills of the students of ZNTU, it might be beneficial to focus more on referring to the background knowledge before reading the text and rereading to remedy comprehension failures. For the students of Taras Shevchenko National University of Kyiv, putting more emphasis on reading for the gist and paying attention to the visuals before reading the first line of every paragraph could be helpful. In addition, taking the linkers into account before considering the other sentences in the paragraph to figure out the meaning of the sentence should be useful.

\section{CONCLUSIONS}

The results of the study were taken into account when designing the Reading module for the students of Radio Engineering, Telecommunications and Economic Studies.

Based on the analysis of the international examinations, a list of activities was compiled to develop the required reading subskills. The activities could be incorporated into teaching in order not only to prepare students for taking international examinations, but to develop students' critical thinking that is essential for their efficient work in the chosen profession. Better involvement of 
the students into the learning process, namely improving their reading skill, can be achieved through selecting the texts related to their specialism.

Focus on teaching reading strategies through the activities that we singled out gives students more confidence when dealing with ESP and taking international examinations in the academic and occupational fields. It makes reading more motivating, effective by decreasing the level of students' anxiety. It leads to an improved learning mood and makes students more responsible for their learning. After all, students start to apply higher-order thinking skills more frequently and enhance their core skills (such as critical thinking and reflection) crucial for their professional growth.

To sum it up, when teaching reading strategies, ESP practitioners should activate students' prior knowledge of content and resort to students' experience, use textual clues to help them cope with new data, enable them to seek information, and, finally, make them successful autonomous learners.

Further study will be focused on developing team work skills of ESP learners through task-based and project-related reading.

\section{REFERENCES}

Afflerbach, P., Pearson, D. and Paris, S. G. (2008) Clarifying differences between reading skills and reading strategies. The Reading Teacher, 61 (5): 364-373. Available from http:// citeseerx.ist.psu.edu/viewdoc/download?doi=10.1.1.848.6320\&rep=rep $1 \&$ type $=$ pdf [Accessed on 15 January 2019].

Alemi, M. and Ebadi, S. (2010) The effects of pre-reading activities on ESP reading comprehension. Journal of Language Teaching and Research, 1 (5): 569-577. Available from https://www.researchgate.net/publication/47716167_The_Effects_of_Pre-reading Activities_on_ESP_Reading_Comprehension [Accessed on $1 \overline{2}$ January $20 \overline{1} 9$ ].

Bakaieva, H. Ye, Borysenko, O. A., Zuyenok, I. I., Ivanishcheva, V. O., Klymenko, L. Yo., Kozymyrska, T. I., Kostrytska, S. I., Skrypnyk, T. I., Todorova, N. Yu. and Khodtseva, A. O. (2005) English for Specific Purposes (ESP). National Curriculum for Universities. Kyiv: Lenvit.

Bezci, E. O. (1998) An Investigation of the Cognitive Reading Strategy Needs of the Freshman Students at Haceteppe University. Ankara: Bilkent University. Available from http:// repository.bilkent.edu.tr/handle/11693/18020 [Accessed on 13 January 2019].

Çelika, H. and Topkayab, E. Z. (2016) Evaluation of the methodology of an ESP reading skills course for undergraduate medical students: Outsider perspective. Procedia - Social and Behavioral Sciences, 232: 326-331 [International Conference on Teaching and Learning English as an Additional Language, GlobELT 2016, 14-17 April 2016, Antalya, Turkey]. Available from https://www.sciencedirect.com/science/article/pii/S1877042816312629/ pdf [Accessed on 12 January 2019].

Dudley-Evans, T. and St. John, M. J. (2012) Developments in English for Specific Purposes. A multidisciplinary approach. Cambridge: Cambridge University Press.

Kamijo, T. (2009) Analyzing the TOEFL ITP Reading Comprehension from a Test Preparation Textbook: A case study and its classroom application (pp. 195-206). Available from http://www. ritsumei.ac.jp/acd/re/k-rsc/lcs/kiyou/pdf_20-4/RitsIILCS_20.4pp.195-206Kamijo.pdf [Accessed on 13 January 2019].

Kashef, S. H., Damavand, A. and Viyani, A. (2012) Strategies-Based ESP Instruction (SBI) of reading comprehension: Male vs. female students. International Journal of Education, 4 (2): 171-180. Available from https://www.researchgate.net/publication/259935822_ 
Strategies-Based_ESP_Instruction_SBI_of_Reading_Comprehension_Male_vs_ Female_Students [Accessed on 15 January 2019].

Omar, A. M. A-T. (2014) An Investigation into the reading strategies of ESP students in the College of Medical Sciences at Umm Al-Qura University. Umm Al-Qura University Journal of Languages and Literatures, 13: 5-46. Available from https://drive.uqu.edu.sa/_/ jll/files/13/5.pdf [Accessed on 15 January 2019].

Ozek, Y. and Civelek, M. (2006) A study on the use of cognitive reading strategies by ELT students. The Asian EFL Journal. Professional Teachers Articles, 14 (1): 1-26. Available from https://asian-efl-journal.com/PTA_August_06_ozec\&civelek.pdf [Accessed on 15 January 2019].

Ratna, A. S. (2014) The use of cognitive reading strategies to enhance EFL students' reading comprehension. International Journal of Education, 2 (1): 1-11. Available from https:// airccse.com/ije/papers/2114ije01.pdf [Accessed on 27 October 2019].

Reza, A. S. M. (2013) Teaching reading strategies to ESP readers. International Journal of Research Studies in Educational Technology, 2 (2): 19-26. Available from https://pdfs.semanticscholar. org/22f4/4e7ec3fb0af511a7387d2533823106c2b11a.pdf [Accessed on 15 January 2019].

Rushwan, I. M. H. (2017) The role of translation in developing ESP learners' reading comprehension skills - a case study of medical students at Najran University-KSA. International Journal of Applied Linguistics \& English Literature, 6 (3): 243-253. Available from http://www.journals.aiac.org.au/index.php/IJALEL/article/view/3097 [Accessed on 12 January 2019].

\section{INTERNET SOURCES}

[Online 1] B1 Business Preliminary. Available from https://www.cambridgeenglish.org/examsand-tests/business-preliminary/exam-format/ [Accessed on 14 January 2019].

[Online 2] B2 Business Vantage. Available from https://www.cambridgeenglish.org/exams-andtests/business-vantage/exam-format/?rows $=24$ [Accessed on 14 January 2019].

[Online 3] C1 Business Higher. Available from https://www.cambridgeenglish.org/exams-andtests/business-higher/exam-format/ [Accessed on 14 January 2019].

[Online 4] BULATS. Preparation. Available from https://www.cambridgeenglish.org/examsand-tests/bulats/preparation/ [Accessed on 14 January 2019].

[Online 5] GMAT Verbal - Reading Comprehension. Some Important pointers about GMAT Verbal - Reading Comprehension. Available from http://www.examfocus.com/gmat/gmatverbal-reading-comprehension.html [Accessed on 13 January 2019].

[Online 6] How to prepare for GMAT. Reading comprehension with non-GMAT texts. Available from https://englishlive.ef.com/blog/career-english/how-to-prepare-for-gmat-readingcomprehension-with-non-gmat-texts/ [Accessed on 13 January 2019].

[Online 7] Frequently asked questions about TOEFL ITP assessment series. Available from https:// www.ets.org/toefl_itp/faq/ [Accessed on 13 January 2019].

[Online 8] About the TOEIC C Listening and Reading Test. Available from https://www.ets.org/ toeic/test-takers/listening-reading/about [Accessed on 14 January 2019].

[Online 9] TOEIC Examinee Handbook. Listening and Reading (2015: 11-14). Available from https://www.ets.org/s/toeic/pdf/listening-reading-examinee-handbook.pdf [Accessed on 14 January 2019].

[Online 10] IELTS Academic Reading. Available from https://www.examenglish.com/IELTS/ IELTS_Academic_reading.html[Accessed on 13 January 2019].

[Online 11] IELTS Guide for teachers. Test format, scoring and preparing students for the test. Available from https://www.ielts.org/-/media/publications/guide-for-teachers/ieltsguide-for-teachers-2017-uk.ashx [Accessed on 13 January 2019]. 
[Online 12] TOLES. Available from https://www.toleslegal.com [Accessed on 13 January 2019].

[Online 13] OET. Reading Sample Test 1. Available from https://prod-wp-content. occupationalenglishtest.org/resources/uploads/2018/06/19145932/Reading-SampleTest-1-Question-Paper-Part-A.pdf [Accessed on 14 January 2019].

[Online 14] OET. Taking the Reading Test. Available from https://www.occupationalenglishtest. org/test-information/reading/ [Accessed on 14 January 2019].

[Online 15] PTE Academic. Available from https://pearsonpte.com/the-test/format/ [Accessed on 13 January 2019].

\section{APPENDIX 1}

Table 1 Reading comprehension in the international examinations in Business English

\begin{tabular}{|c|c|c|}
\hline \begin{tabular}{|l|} 
Examination \\
\end{tabular} & Reading subskills tested & Types of tasks \\
\hline $\begin{array}{l}\text { B1 Business } \\
\text { (Online 1) }\end{array}$ & $\begin{array}{l}\text { - skimming, } \\
\text { - scanning, } \\
\text { - reading and understanding } \\
\text { visual information, } \\
\text { - reading and finding detailed } \\
\text { factual info, } \\
\text { - understanding the structure of } \\
\text { the text, } \\
\text { - reading and transferring info }\end{array}$ & $\begin{array}{l}\text { - multiple-choice, } \\
\text { - matching, } \\
\text { - Right/Wrong/Doesn't say, } \\
\text { - multiple-choice cloze, } \\
\text { - note completion }\end{array}$ \\
\hline $\begin{array}{l}\text { B2 Business } \\
\text { Vantage } \\
\text { (Online 2) }\end{array}$ & $\begin{array}{l}\text { - scanning, } \\
\text { - skimming, } \\
\text { - understanding the structure of } \\
\text { the text, } \\
\text { - proofreading }\end{array}$ & $\begin{array}{l}\text { - matching, } \\
\text { - multiple choice, } \\
\text { - multiple choice cloze, } \\
\text { - proofreading }\end{array}$ \\
\hline $\begin{array}{l}\text { C1 Business } \\
\text { Higher } \\
\text { (Online 3) }\end{array}$ & $\begin{array}{l}\text { - scanning, } \\
\text { - skimming, } \\
\text { - understanding the structure } \\
\text { of the text and features of } \\
\text { the discourse, } \\
\text { - proofreading }\end{array}$ & $\begin{array}{l}\text { - multiple choice, } \\
\text { - multiple choice cloze, } \\
\text { - open cloze, } \\
\text { - proofreading }\end{array}$ \\
\hline $\begin{array}{l}\text { BULATS } \\
\text { (Online 4) }\end{array}$ & $\begin{array}{l}\text { - skimming, } \\
\text { - scanning, } \\
\text { - deducing meaning from context }\end{array}$ & $\begin{array}{l}\text { multiple choice (a notice, diagram, } \\
\text { memo, label, letter - choose the } \\
\text { sentence/phrase closest to the } \\
\text { meaning of the text), } \\
\text { - gapped sentences, } \\
\text { - multiple-choice gap-fill, } \\
\text { - one gap-fill, } \\
\text { - extended reading (several questions } \\
\text { to the text) }\end{array}$ \\
\hline $\begin{array}{l}\text { GMAT } \\
\text { (Online 5, } \\
\text { Online 6) } \\
\end{array}$ & $\begin{array}{l}\text { - drawing inferences, based } \\
\text { on implied information, but } \\
\text { supported with the pointers }\end{array}$ & multiple choice \\
\hline
\end{tabular}


Table 2 Reading comprehension in the international ESP and EAP examinations

\begin{tabular}{|c|c|c|}
\hline Examination & Reading subskills tested & Types of tasks \\
\hline $\begin{array}{l}\text { TOEFL ITP } \\
\text { (Kamijo, } \\
\text { 2009: } \\
\text { 197-198; } \\
\text { Online 7) }\end{array}$ & $\begin{array}{l}\text { - scanning text for facts and } \\
\text { important information; } \\
\text { - increasing reading fluency; } \\
\text { - understanding the general topic } \\
\text { or main idea, major points, } \\
\text { important facts, and details, } \\
\text { vocabulary in context, and } \\
\text { pronoun references; } \\
\text { - making inferences about what is } \\
\text { implied in a passage; } \\
\text { - recognizing the organization } \\
\text { and purpose of a passage; } \\
\text { - understanding relationships } \\
\text { between ideas; } \\
\text { - organizing information into } \\
\text { a category chart or a summary in } \\
\text { order to recall major information } \\
\text { and important details; } \\
\text { - inferring how ideas throughout } \\
\text { the passage connect }\end{array}$ & $\begin{array}{l}\text { multiple choice (identifying the main } \\
\text { idea of the passage; reading for detail) }\end{array}$ \\
\hline $\begin{array}{l}\text { TOEIC } \\
\text { (Online 8, } \\
\text { Online 9) }\end{array}$ & $\begin{array}{l}\text { - skimming, } \\
\text { - scanning, } \\
\text { - inferring, } \\
\text { - deducing meaning from context }\end{array}$ & $\begin{array}{l}\text { multiple choice (complete } \\
\text { the sentences / the text, answer } \\
\text { the question) }\end{array}$ \\
\hline $\begin{array}{l}\text { IELTS } \\
\text { Academic } \\
\text { (Online 10, } \\
\text { Online 11) } \\
\end{array}$ & $\begin{array}{l}\text { - skimming, } \\
\text { - scanning, } \\
\text { - inferring, } \\
\text { - deducing meaning from context }\end{array}$ & $\begin{array}{l}\text { - multiple choice } \\
\text { - identifying information (True/False/ } \\
\text { Not Given) } \\
\text { - identifying writer's claims/views }\end{array}$ \\
\hline $\begin{array}{l}\text { TOLES } \\
\text { (Online 12) }\end{array}$ & $\begin{array}{l}\text { - skimming, } \\
\text { - scanning, } \\
\text { - inferring, } \\
\text { - deducing meaning from context, } \\
\text { - proofreading, } \\
\text { - editing }\end{array}$ & $\begin{array}{l}\text { - find a wrong/extra word } \\
\text { - true/false statements } \\
\text { - put the conversation in the correct } \\
\text { order } \\
\text { - put each phrase under the correct area } \\
\text { of law } \\
\text { - put the correct word in the sentence } \\
\text { - match the words in the text with } \\
\text { the correct meaning } \\
\text { - answer the questions using a full } \\
\text { sentence } \\
\text { - choose the correct preposition } \\
\text { - explain the meaning of the underlined } \\
\text { words/phrases } \\
\text { - give a brief description of } \\
\text { the underlined words/phrases as they } \\
\text { are used in this section of the contract }\end{array}$ \\
\hline
\end{tabular}




\begin{tabular}{|l|l|l|}
\hline Examination & \multicolumn{1}{|c|}{ Reading subskills tested } & \multicolumn{1}{c|}{ Types of tasks } \\
\hline & & $\begin{array}{l}\text { - give an alternative to each underlined } \\
\text { word / add an additional word / delete } \\
\text { a word to create an accurate, formal } \\
\text { and professional email } \\
\text { - use the given word to form a new one } \\
\text { and fill in the space } \\
\text { give a short explanation of } \\
\text { the idiomatic expression } \\
\text { - explain the meaning of each contract } \\
\text { clause in plain English }\end{array}$ \\
\hline $\begin{array}{l}\text { OET } \\
\text { Online 14) }\end{array}$ & $\begin{array}{l}\text { - scanning, } \\
\text { - inferring, } \\
\text { - deducing meaning from context }\end{array}$ & $\begin{array}{l}\text { Look through the text, find the relevant } \\
\text { info: } \\
\text { - for each question, decide which text } \\
\text { the information comes from } \\
\text { answer the questions with a word/ } \\
\text { short phrase from one of the texts } \\
\text { complete each sentence with a word/ } \\
\text { a short phrase from one of the texts }\end{array}$ \\
\hline $\begin{array}{l}\text { PTE } \\
\text { Academic } \\
(\text { Online 15) }\end{array}$ & $\begin{array}{l}\text { - scanning, } \\
\text { skimming, } \\
\text { understanding the structure of } \\
\text { the text }\end{array}$ & $\begin{array}{l}\text { fill in the blanks } \\
\text { re-order paragraphs } \\
\text { - multiple choice (choose multiple } \\
\text { answers / single answer) }\end{array}$ \\
\hline
\end{tabular}

\section{APPENDIX 2}

\section{Questionnaire on the Usage of the Reading Strategies}

Tick the box which is true of you opposite to each statement: 'Always true of me', 'Usually true of me', 'Sometimes true of me', 'Rarely true of me', 'Never true of me'.

\section{Pre-reading strategies}

1.1. Reading the title and imagining what the title might be about

1.2. Looking at illustrations/pictures and guessing how they relate to the text

1.3. Reading over the text quickly to get the main idea (gist)

1.4. Thinking about previous knowledge on the topic of the text

1.5. Reading the first line of every paragraph to understand what the text is about

\section{While-reading strategies}

2.1. Reading without looking up every unknown word in the dictionary

2.2. Using the dictionary for the important words

2.3. Guessing the meaning of a word from the context

2.4. Guessing the meaning of the word from the grammatical category

2.5. Remembering a new word by thinking of a situation in which a word might be used 


\subsection{Skipping words}

2.7. Rereading a sentence

2.8. Considering the other sentences in the paragraph to figure out the meaning of the sentence

2.9. Reading without translating word-for-word

2.10. Having the picture of the events in the text in mind

2.11. Paying attention to words or phrases that show how the text is organized

2.12. Taking notes on the important points of the text

2.13. Making guesses about what will come next based on the information already given in the text

2.14. Relating the text to background knowledge about the topic to remember important information

\section{Post-reading strategies}

3.1. Summarizing the main ideas

3.2. Classifying the words according to their meaning

3.3. Rereading the text to remember important points

3.4. Rereading the text to remedy the comprehension failures

3.5. Classifying the words according to their grammatical category

Nataliia Zhukova ( $\mathrm{PhD}$ in Philology (Germanic Languages), Associate Professor) is currently working at National University 'Zaporizhzhia Polytechnic'. The research interests include language acquisition, English for Specific Purposes teaching, English for Academic Purposes teaching, cognitive linguistics. Email: nmzhukova@gmail.com

Iryna Didenko (PhD in Pedagogy, Professional Award in Teacher Development, Assistant Professor, teacher trainer) is currently teaching English for Specific Purposes at Taras Shevchenko National University of Kyiv. Academic and research fields embrace teaching English for Specific and Academic Purposes: core skills, assessment and evaluation, classroom management, motivation, soft skills acquisition.Email: ir-za@i.ua 